\title{
Foliar application of citric and malic acid to stock plants of rose alters the rooting of stem cuttings
}

Noushin Ghazijahani', Ebrahim Hadavi ${ }^{2 *}$ (], Moon S. Son ${ }^{3}$ and Byoung R. Jeong ${ }^{3}$

\begin{abstract}
Background: As the world's best-selling cut flower, there is a high demand for propagated rose plants. Auxins are the dominant growth regulator used to improve the rooting of cutting; however, their application remains a labor-intensive process, and on the other hand, side effects like poor shoot growth exist. Organic acid sprays have enhanced many physiological traits of plants which justified surveying their possible effect on the rooting process in the current study.

Methods: Different concentrations of citric or malic acid were sprayed to stock plants of rose (Rosa x hybrida CV. 'Sherbet') prior to taking cuttings. Malic or citric acid (3, 6, or $9 \mathrm{mM}$ ) was applied five times on a 14-day interval in a commercial cut flower production greenhouse. Single-node cuttings were prepared and were rooted under mist. Data collected included rooting percentage, root count, root and shoot length and dry weight, and root-to-shoot ratio (R:S).
\end{abstract}

Results and discussion: The rooting percentage was enhanced by all treatments. Citric acid enhanced root number at $6 \mathrm{mM}$ level followed by $3 \mathrm{mM}$ citric acid. Average root length was increased by all treatments except 3 and $6 \mathrm{mM}$ malic acid. All CA treatments increased shoot length, while it remained unaffected by MA treatments. CA at 3 and $6 \mathrm{mM}$ level and $6 \mathrm{mM}$ MA increased shoot dry weight, but only $9 \mathrm{mMCA}$ increased the root dry weight.

Conclusion: Both organic acids had positive effects on rooting response of 'Sherbet' roses. However, the mechanism of observed responses to organic acids remains to be studied. While they enhance the physiological performance of stock plants, they can also simultaneously both enhance the rooting as well as the shoot growth of the new plantlets.

Keywords: Adventitious rooting, Foliar spray, Organic acids, Propagation, Rosa x hybrida, Root count

\section{Background}

The global import of cut flowers into the US totaled over 1 billion dollars in 2016 [1]. Cut roses are a significant component of imported flowers. Annual growth in the value of rose cut flowers between 2010 and 2014 was 6\%, which was the highest among cut flowers [2]. To meet the growing demand, roses are commonly propagated by stem cuttings which are usually treated with a synthetic auxin to promote the formation of adventitious roots. However, applied auxins usually inhibit subsequent bud

\footnotetext{
*Correspondence: hadavi@kiau.ac.ir

2 Department of Horticultural Sciences, Islamic Azad University, Karaj Branch, Karaj, Iran

Full list of author information is available at the end of the article
}

development of cuttings in apple [3] and rose [4, 5]. Wiesman et al. [6, 7] showed that applied indole-3-butyric acid (IBA) at the cutting base was transported to the upper part of the cutting. Sun et al. [5] concluded that after the applied auxin is transported to the upper part of the cutting, it causes increased ethylene production. Therefore, despite of adequate rooting, high concentrations of auxins may prevent shoot growth or cause the whole young shoots to abscise after the bud-break $[8,9]$.

The alternate foliar application of auxin on cutting has been tested in many studies and is reviewed by Blythe [10]. In studies on woody plants and some herbaceous species, it is concluded as ineffective [11, 12], while others usually working on herbaceous species could find 
results that were comparable with basal application method [13-17]. However, Blythe reported that a single application of auxin on single-node cuttings of miniature rose did not affect on rooting [18]. The spray of the stock plant with an auxin, prior to cutting collection, has been tried before by Stoutemyer and O'Rourke [19] who sprayed the stock plants of several woody ornamentals with selected concentrations of the auxins and prepared cuttings from the treated plants after several days or weeks. Their results suggested that cuttings taken from the plants treated with auxins show essentially the same rooting responses as cuttings treated with generally accepted methods of application. Whatley et al. [20] sprayed stock plants of rose once 10 days before cutting collection using a solution containing NAA or soaked the cuttings in IBA for $15 \mathrm{~min}$. They observed that cuttings receiving soak treatment rooted better than cuttings receiving the foliar spray, while both treatments rooted better than the non-treated cuttings. Alternative approaches to the problem are tested by Scagel [21], who showed that addition of vesicular-arbuscular mycorrhizal fungi (VAMF) to the rooting medium of two-node cuttings from five cultivars of miniature roses increased the rooting percentage and root count per cutting.

Endogenous organic acids are both a source of carbon skeletons for other biochemical pathways as well as an energy source for cells in the respiratory cycle [22]. In plants, malic acid (MA) is metabolized in mitochondria, acts as a common reserve anion in the plant vacuole, and is a counter ion for $\mathrm{K}$ and Ca cations, especially in nitrate-dependent plants [23-25]. Citrate and malate extruded by roots of calcicole plants (plants growing in alkaline soils) facilitate the extraction of phosphorus and iron from such soils [26]. Citric acid (CA) alone or in combination with iron sources has been sprayed on the foliage of plants for successful recovery from iron chlorosis [27-30]. Use of CA alone or in combinations with salicylic acid (SA) and MA increased the essential oil production of Ocimum basilicum L. and Anethum graveolens L. [31, 32]. Foliar application of CA extended the vase life of lily (Lilium spp.) and tuberose (Polianthes tuberosa L.) while improving drought tolerance in bean (Phaseolus vulgaris L.) [30, 33, 34]. Combination of $1 \mathrm{mM}$ SA with $7 \mathrm{mM} \mathrm{CA}$ was superior to others for improving flowering and essential oil production in Ocimum basilicum L. [35]. The level of CA inside plant tissue is increased by exogenous application of $\mathrm{CA}$ and beneficial effects were observed, which were attributed to observed protective effects on peroxidation-linked membrane deterioration, free radical scavenging, maintenance of membrane stability, an increase in root activity, and activation of an antioxidant response [36]. The increase in peroxidase activity from CA application, which is responsible for
$\mathrm{H}_{2} \mathrm{O}_{2}$ metabolism, has been documented [37]. IBA is responsible for an $\mathrm{H}_{2} \mathrm{O}_{2}$ increase, which promotes the formation of adventitious roots, possibly via a change in antioxidant enzymes activity; the same rooting response is reported with the addition of either ascorbic acid or $\mathrm{H}_{2} \mathrm{O}_{2}$ [38].

Considering the role of antioxidative enzyme systems in the adventitious rooting process and the reported effect of CA on it, we hypothesized a possible role for certain organic acids in the rooting process. The 'Sherbet' variety is among the important local varieties with an appealing white flower which was selected for the current study. The objective of this research was to evaluate the applications of CA and MA to stock plants on the rooting of rose cuttings.

\section{Methods}

Rose stock plants (Rosa $x$ hybrida cv. 'Sherbet') were grown in a commercial hydroponic cut rose production greenhouse near Gimhae $\left(35^{\circ} 15^{\prime} 47.0^{\prime \prime} \mathrm{N} 128^{\circ} 45^{\prime} 41.9^{\prime \prime} \mathrm{E}\right)$, Korea. During the day, heating was applied when the air temperature in the greenhouse was lower than $16{ }^{\circ} \mathrm{C}$ $(289 \mathrm{~K})$ and ventilation was provided when higher than $30{ }^{\circ} \mathrm{C}$ (303). The plants depended on a natural light regime as no supplemental lighting was used. Starting on September 17, the plants were sprayed every 14 days (total of five times) with one of seven treatments. Treatments consisted of CA or MA (Sigma-Aldrich, St. Louis, MO, USA) each at 3,6 , or $9 \mathrm{mM}$ and a distilled water (DW) control. A few drops of surfactant (Tween 20, Fisher Scientific, Hampton, NH) were added to all sprays. The sprays were applied until run-off. The experiment was conducted in a completely randomized design and each treatment was replicated three times. In each replication, there were ten stock plants per treatment (210 total stock plants). Shoot bending (training part of shoots to grow downward) was practiced and cut flower harvest was continued as usual. At 14 days after the fifth spray, the available unopened flower stems were harvested, placed in buckets containing distilled water, and were immediately transferred to a greenhouse of the Horticulture Department at Gyeongsang National University, Jinju, South Korea. Single-node cuttings were cut from the middle part of the shoots; each cutting had a single leaf from which the terminal leaflet was removed. Twelve cuttings (subsamples) were taken from each of the three replications (36 total cuttings per each treatment) and were put immediately in rock-wool cubes ( $5 \mathrm{~cm}$ by $5 \mathrm{~cm}$ by $5 \mathrm{~cm}$; Grodan, Denmark) and placed in a fog propagation tunnel for 3 weeks and then under intermittent mist for another 3 weeks inside a research greenhouse at the same institution. The environmental condition maintained during rooting was $98 \pm 2 \%$ relative 
humidity and $18-25{ }^{\circ} \mathrm{C}(298 \mathrm{~K})$ with $40 \%$ shading of the natural sunlight. After a 6-week rooting period, the data were collected. Percentage of cuttings with evident roots (rooting percentage) and the number of roots per cutting were counted (root count) in each plantlet. Then, the roots were detached from each plantlet, and the mean and longest root length were measured in each. The shoots were detached as well and their length was determined. Finally, the detached shoots and roots were pooled for each replication and were subsequently dried in a dry oven at $70{ }^{\circ} \mathrm{C}$ (343) for $72 \mathrm{~h}$, and the dry weight of each was measured. The collected data were analyzed for mean separation in 'multivariate' analysis module of SPSS (IBM Corp. Released 2012. IBM SPSS Statistics for Windows, Version 21.0. Armonk, NY), using Duncan's multiple range test option at $p<.05$ level and the correlations were determined by two-tailed Pearson correlation option of the same software package.

\section{Results and discussion Rooting percentage}

The rooting percentage was $94.6 \%$ in the control treatment (DW), $97 \%$ in $3 \mathrm{mM} \mathrm{CA}$, and $100 \%$ in the remaining treatments (Table 1). While much of organic acid treatments statistically show an improved rooting percentage, but the difference is not as much to be considered substantial. Our results support the conclusion by Pivetta et al. who reported that there is no need for IBA application for rooting of rose cuttings [39]. However, earlier reports had suggested the 'Sherbet' variety to be an easy-to-root type [40], though the rooting percentage is only the initial requirement of a successful propagation and could not predict the subsequent performance of plants (detailed experimental data for all traits is provided in Additional file 1).

\section{Root count}

This is a key index to judge on the rooting quality. CA at 3 and $6 \mathrm{mM}$ had the greatest mean root count per cutting which was significantly higher than the control but on par with other organic acid treatments (Table 1). Root count was correlated significantly and positively with the mean root length and the longest root length, which suggests that increased root count did not compromise the root length (Table 2).

\section{Longitudinal root and shoot growth parameters}

Both mean root length and the longest root length were improved with treatments of CA 3 and $6 \mathrm{mM}$ and MA $9 \mathrm{mM}$ (Table 1). Interestingly, with the exception of $9 \mathrm{mM}$ MA, a similar pattern was noted in shoot growth. As shown in Table 1, MA at $9 \mathrm{mM}$ level caused retarded shoot growth that was even significantly lower than the control treatment. Only $9 \mathrm{mM}$ CA increased root dry weight (Table 1).

\section{Root/shoot ratio}

There was a little difference in root/shoot ratio (R:S) between treatments. However, a significant positive correlation between $\mathrm{R}: \mathrm{S}$ and root dry weights persists, which suggests that an increase in the root growth could have been the cause of increased R:S (Table 2), even though a significant negative correlation between shoot dry weight and R:S suggests that at least part of its increase could be

Table 1 Effect of citric acid (CA) and malic acid (MA) spray treatments on rooting of herbaceous cuttings in 'Sherbet' roses

\begin{tabular}{|c|c|c|c|c|c|c|c|c|c|c|c|c|c|c|c|c|}
\hline \multirow{2}{*}{$\begin{array}{l}\text { Treatment } \\
\text { DW }\end{array}$} & \multicolumn{2}{|c|}{$\begin{array}{l}\text { Rooting per- } \\
\text { centage (\%) }\end{array}$} & \multicolumn{2}{|c|}{ Root count } & \multicolumn{2}{|c|}{$\begin{array}{l}\text { Mean root } \\
\text { length }(\mathrm{mm})\end{array}$} & \multicolumn{2}{|c|}{$\begin{array}{l}\text { Longest root } \\
\text { length }(\mathrm{mm})\end{array}$} & \multicolumn{2}{|c|}{$\begin{array}{l}\text { Shoot length } \\
(\mathrm{mm})\end{array}$} & \multicolumn{2}{|c|}{$\begin{array}{l}\text { Shoot dry } \\
\text { weight (g) }\end{array}$} & \multicolumn{2}{|c|}{$\begin{array}{l}\text { Root dry } \\
\text { weight (g) }\end{array}$} & \multicolumn{2}{|c|}{$\begin{array}{l}\text { Root/ } \\
\text { shoot } \\
\text { ratio (DW) }\end{array}$} \\
\hline & $\begin{array}{l}94.6 \\
( \pm 4.62)\end{array}$ & $b$ & $\begin{array}{l}4.6 \\
( \pm .6)\end{array}$ & $b$ & $\begin{array}{l}25.2 \\
( \pm 1.6)\end{array}$ & $b$ & $\begin{array}{l}39.2 \\
( \pm 6.6)\end{array}$ & C & $\begin{array}{l}54.9 \\
( \pm 5.1)\end{array}$ & $b c$ & $\begin{array}{l}.090 \\
( \pm .016)\end{array}$ & C & $\begin{array}{l}.012 \\
( \pm .002)\end{array}$ & $b$ & $\begin{array}{l}.14 \\
( \pm .01)\end{array}$ & $a b$ \\
\hline CA $3 \mathrm{mM}$ & $\begin{array}{l}97 \\
( \pm 5.2)\end{array}$ & $a b$ & $\begin{array}{l}7.1 \\
( \pm .4)\end{array}$ & a & $\begin{array}{l}33.1 \\
( \pm 3)\end{array}$ & $\mathrm{a}$ & $\begin{array}{l}51.9 \\
( \pm 7.5)\end{array}$ & $\mathrm{a}$ & $\begin{array}{l}77 \\
( \pm 5.5)\end{array}$ & a & $\begin{array}{l}.138 \\
( \pm .022)\end{array}$ & $a b$ & $\begin{array}{l}.018 \\
( \pm .002)\end{array}$ & $a b$ & $\begin{array}{l}.13 \\
( \pm .03)\end{array}$ & $a b$ \\
\hline CA $6 \mathrm{mM}$ & $\begin{array}{l}100 \\
( \pm 0)\end{array}$ & a & $\begin{array}{l}7.7 \\
( \pm .8)\end{array}$ & a & $\begin{array}{l}34.5 \\
( \pm 1.4)\end{array}$ & a & $\begin{array}{l}51.1 \\
( \pm 3)\end{array}$ & a & $\begin{array}{l}79.8 \\
( \pm 5.2)\end{array}$ & $\mathrm{a}$ & $\begin{array}{l}.148 \\
( \pm .033)\end{array}$ & a & $\begin{array}{l}.017 \\
( \pm .002)\end{array}$ & $a b$ & $\begin{array}{l}.12 \\
( \pm .02)\end{array}$ & $a b$ \\
\hline CA $9 \mathrm{mM}$ & $\begin{array}{l}100 \\
( \pm 0)\end{array}$ & $a$ & $\begin{array}{l}6.5 \\
( \pm .6)\end{array}$ & $a b$ & $\begin{array}{l}35.2 \\
( \pm 4.6)\end{array}$ & a & $\begin{array}{l}48.7 \\
( \pm 3.2)\end{array}$ & $a b$ & $\begin{array}{l}73.7 \\
( \pm 2.8)\end{array}$ & a & $\begin{array}{l}.124 \\
( \pm .003)\end{array}$ & $a b c$ & $\begin{array}{l}.023 \\
( \pm .007)\end{array}$ & $a$ & $\begin{array}{l}.19 \\
( \pm .06)\end{array}$ & a \\
\hline MA $3 \mathrm{mM}$ & $\begin{array}{l}100 \\
(0)\end{array}$ & a & $\begin{array}{l}6.1 \\
( \pm 1.9)\end{array}$ & $a b$ & $\begin{array}{l}29.7 \\
( \pm 5.5)\end{array}$ & $a b$ & $\begin{array}{l}41.1 \\
( \pm 7.5)\end{array}$ & $b c$ & $\begin{array}{l}63 \\
( \pm 6.7)\end{array}$ & $a b$ & $\begin{array}{l}.113 \\
( \pm .014)\end{array}$ & $b c$ & $\begin{array}{l}.017 \\
( \pm .006)\end{array}$ & $a b$ & $\begin{array}{l}.15 \\
( \pm .07)\end{array}$ & $a b$ \\
\hline MA 6 mM & $\begin{array}{l}100 \\
(0)\end{array}$ & a & $\begin{array}{l}6.7 \\
( \pm 1.3)\end{array}$ & $a b$ & $\begin{array}{l}29.4 \\
( \pm .5)\end{array}$ & $a b$ & $\begin{array}{l}47 \\
( \pm .1)\end{array}$ & $b c$ & $\begin{array}{l}39.1 \\
( \pm 3.7)\end{array}$ & $\mathrm{cd}$ & $\begin{array}{l}.151 \\
( \pm .011)\end{array}$ & a & $\begin{array}{l}.015 \\
( \pm .005)\end{array}$ & $a b$ & $\begin{array}{l}.10 \\
( \pm .03)\end{array}$ & $b$ \\
\hline MA $9 \mathrm{mM}$ & $\begin{array}{l}100 \\
(0)\end{array}$ & a & $\begin{array}{l}6.0 \\
( \pm 1.6)\end{array}$ & $a b$ & $\begin{array}{l}34.3 \\
( \pm 1.49)\end{array}$ & $\mathrm{a}$ & $\begin{array}{l}49.3 \\
( \pm 1.6)\end{array}$ & $a b$ & $\begin{array}{l}34 \\
( \pm 23)\end{array}$ & $d$ & $\begin{array}{l}.096 \\
( \pm .012)\end{array}$ & c & $\begin{array}{l}.017 \\
( \pm .003)\end{array}$ & $a b$ & $\begin{array}{l}.18 \\
( \pm .03)\end{array}$ & $a b$ \\
\hline
\end{tabular}

Means with similar letters are not statistically different based on Duncan's test $(p<.05)$

The value in parentheses is the standard deviation 
Table 2 Cross correlations between observed traits

\begin{tabular}{|c|c|c|c|c|c|c|c|c|}
\hline & Root count & $\begin{array}{l}\text { Mean root } \\
\text { length }(\mathrm{mm})\end{array}$ & $\begin{array}{l}\text { Longest root } \\
\text { length }(\mathrm{mm})\end{array}$ & $\begin{array}{l}\text { Shoot length } \\
(\mathrm{mm})\end{array}$ & $\begin{array}{l}\text { Shoot dry } \\
\text { weight (g) }\end{array}$ & $\begin{array}{l}\text { Root dry } \\
\text { weight (g) }\end{array}$ & $\begin{array}{l}\text { Root/shoot } \\
\text { ratio (DW) }\end{array}$ & $\begin{array}{l}\text { Rooting } \\
\text { percentage } \\
(\%)\end{array}$ \\
\hline $\begin{array}{l}\text { Whole cutting } \\
\text { fresh weight } \\
\text { (g) }\end{array}$ & $.612^{* *}$ & $.599^{* *}$ & .352 & .290 & $.668^{* *}$ & .387 & -.085 & $.501^{*}$ \\
\hline Root count & & $.503^{*}$ & $.578^{* *}$ & .176 & $.604^{* *}$ & $.594^{* *}$ & .149 & .315 \\
\hline $\begin{array}{l}\text { Mean root } \\
\text { length (mm) }\end{array}$ & & & $.798^{* *}$ & .304 & .183 & $.441^{*}$ & .268 & $.442^{*}$ \\
\hline $\begin{array}{l}\text { Longest root } \\
\text { length }(\mathrm{mm})\end{array}$ & & & & .188 & .274 & .388 & .183 & $.482^{*}$ \\
\hline $\begin{array}{l}\text { Shoot length } \\
(\mathrm{mm})\end{array}$ & & & & & .308 & .210 & -.058 & .035 \\
\hline $\begin{array}{l}\text { Shoot dry } \\
\text { weight (g) }\end{array}$ & & & & & & .147 & $-.498^{*}$ & .286 \\
\hline $\begin{array}{l}\text { Root dry } \\
\text { weight (g) }\end{array}$ & & & & & & & $.772^{* *}$ & .272 \\
\hline $\begin{array}{l}\text { Root/shoot } \\
\text { ratio (DW) }\end{array}$ & & & & & & & & .081 \\
\hline
\end{tabular}

*Correlation is significant at $p<.05 ;{ }^{* *}$ correlation is significant at $p<.01$

due to more partitioning of carbohydrates to root system rather than the shoot.

A significant positive correlation between root count and mean root length, longest root length, and root and shoot dry weight was observed (Table 2). This suggests that root count could be a key qualitative feature of rooting, which is correlated to other important rooting parameters.

Six and 9 mM MA created a distinct pattern of growth characterized by less longitudinal shoot growth than the longest root growth, which was opposite to what was observed in the rest of the treatments including the control. However, If we consider the effect of above-mentioned MA levels to be due to increased growth of root as compared to shoot we may expect to note an increase in weight of root or R:S ratio which is not the case as is evident in Table 1 . Therefore, we may assume that the mentioned treatments reduced the shoots length, which was possibly compromised somehow to keep the weight unchanged.

In our experiment, all the treatments, except for $3 \mathrm{mM}$ CA, caused improved rooting percentage, even though it was a slight improvement as compared to control. We conclude that MA treatments did not cause a statistically significant improvement in rooting response compared to the DW treatment. However, the mechanism of observed responses to organic acids remains unclear. Induction of citrate production by exogenous citrate is shown in microorganisms and later in plants which could describe the changes in internal homeostasis of organic acids as the possible key to further changes in plant metabolism pattern. Changes in the pattern of carbohydrate distribution in the plant $[30,35,41]$ have been reported which could be effective in rooting potential of cuttings. Hu et al. [36] reported that endogenous citric acid levels in the leaf tissue of tall fescue (Lolium arundinaceum Schreb.) increased significantly following the external application of citric acid. This coincided with an increase in tolerance of plants to heat stress. They reported that protective effects on peroxidationlinked membrane deterioration, free radicals scavenging, maintenance of membrane stability, an increase in root activity, and activation of antioxidant response and HSP genes coincided with induced heat stress tolerance by citric acid. A similar response may be present in our study; however, more data is needed to understand the mode of action of organic acids on rooting process. Enzymatic, Proteomic and/or genomic approaches may help to better comprehend the pattern of changes exerted by applied foliar organic acid treatments.

\section{Conclusion}

By use of organic acids, we could avoid the reported negative effects of auxins on the subsequent shoot growth of treated plants $[4,5,8,9]$. Organic acid sprays might serve as an alternative to hormonal treatments of rose stock plants. We have to bear in mind that, in addition to the reported effect on rooting in the current study, unlike most PGRs, these organic acids improve the growth and adaptation indices of plants as well which is mentioned earlier. Therefore, these organic acids are considered potential low-cost and environmentally friendly plant biostimulants, which can improve plant growth, adaptability, and rooting parameters as established here. 
However, further work is needed to conclude on the commercial aspects of these agents for the nursery industry.

\section{Additional file}

Additional file 1. The detailed data of all measured traits.

\section{Authors' contributions}

NG and MSS and BRJ have participated in study design and field operations, and the data were analyzed and the manuscript was prepared by $\mathrm{EH}$. All authors read and approved the final manuscript.

\section{Author details}

${ }^{1}$ Department of Microbiology, Islamic Azad University, Karaj Branch, Karaj, Iran. ${ }^{2}$ Department of Horticultural Sciences, Islamic Azad University, Karaj Branch, Karaj, Iran. ${ }^{3}$ Department of Horticulture, Gyeongsang National University, Jinju 660-701, Republic of Korea.

\section{Acknowledgements}

The authors wish to thank C. H. Hwang and C. H. Ko for their kind help during the experiment.

Chemicals used in this study: citric acid and malic acid.

Species used in this study: Rose (Rosa hybrida L.'Sherbet').

\section{Competing interests}

The authors declare that they have no competing interests.

\section{Availability of data and materials}

The data set supporting the conclusions of this article is available as additional supporting files.

\section{Consent for publication}

The authors declare that they grant the permission to publish this article to Springer-Verlag $\mathrm{GmbH}$ Berlin Heidelberg. They also agree to transfer the copyright to the article as well to above-mentioned publisher. The authors will do this in consensus to the copyright transfer form of the publisher and will sign it accordingly.

Ethics approval and consent to participate Not applicable.

\section{Funding}

The research was cofounded by IAU and GNU.

\section{Publisher's Note}

Springer Nature remains neutral with regard to jurisdictional claims in published maps and institutional affiliations.

Received: 10 December 2017 Accepted: 11 May 2018

Published online: 21 May 2018

\section{References}

1. Imported: Fresh-cut flowers. 2017. https://www.ustradenumbers.com. Accessed 7 Jul 2017.

2. ITC. Market Analysis and Research, International Trade Centre (ITC). 2014.

3. Christensen MV, Eriksen EN, Andersen AS. Interaction of stock plant irradiance and auxin in the propagation of apple rootstocks by cuttings. Sci Hortic. 1980;12(1):11-7.

4. De Vries D, Dubois LA. The effect of BAP and IBA on sprouting and adventitious root formation of 'Amanda' rose single-node softwood cuttings. Sci Hortic. 1988;34(1):115-21.
5. Sun W-Q, Bassuk NL. Auxin-induced ethylene synthesis during rooting and inhibition of bud break of 'Royalty' rose cuttings. J Am Soc Hortic Sci. 1993;118(5):638-43.

6. Wiesman Z, Riov J, Epstein E. Comparison of movement and metabolism of indole-3-acetic acid and indole-3-butyric acid in mung bean cuttings. Physiol Plant. 1988;74(3):556-60.

7. Wiesman Z, Riov J, Epstein E. Characterization and rooting ability of indole-3-butyric acid conjugates formed during rooting of mung bean cuttings. Plant Physiol. 1989;91(3):1080-4.

8. Hartmann HT, Kester DE, Davis FT. Plant propagation: principles and practices. Englewood Cliffs: Prentice-Hall; 1990.

9. Bassil NV, et al. Propagation of hazelnut stem cuttings using Agrobacterium rhizogenes. HortScience. 1991;26(8):1058-60.

10. Blythe EK, et al. Methods of auxin application in cutting propagation: a review of 70 years of scientific discovery and commercial practice. J Environ Hortic. 2007:25(3):166-85.

11. Blythe EK, et al. Cutting propagation of foliage crops using a foliar application of auxin. Sci Hortic. 2004;103(1):31-7.

12. Tincker M. Further experiments with growth substances and the rooting of cuttings. J. Royal Hortic Soc. 1938;63:210-29.

13. Blythe EK, et al. Evaluation of an alternative method of rooting hormone application in cutting propagation. Comb Proc Intl Plant Prop Soc. 2002;52:393-9.

14. Hildreth A, Mitchell J. Spraying is a new method of applying root-promoting substances. Florists'Rev. 1939;84:13.

15. Mitchell JW, Marth PC. Growth regulators for garden, field, and orchard. Chicago: The University of Chicago Press; 1947.

16. Kroin J. Advances using indole-3-butyric acid (IBA) dissolved in water for rooting cuttings, transplanting, and grafting. In: Combined proceedingsinternational plant propagators society. Univ Washington-Int Plant Propagation Soc; 1992.

17. Blythe EK, et al. Foliar application of auxin for rooting stem cuttings of selected ornamental crops. J Environ Hortic. 2003:21(3):131-6.

18. Blythe EK, et al. Rooting of rose cuttings in response to foliar applications of auxin and surfactant. HortTechnology. 2004;14(4):479-83.

19. Stoutemyer $V$, Orourke F. Rooting of cuttings from plants sprayed with growth regulating substances. In: Proceedings of the American society for horticultural science. Amer Soc Horticultural Science 701 North Saint Asaph Street, Alexandria; 1945.

20. Whatley B, Thompson S, Williams G Jr. The effects of nutrient solution, foliar spray, 3-indolebutyric acid and dimethyl sulfoxide (DMSO) on rooting of hibiscus cuttings. Comb Proc Intl Plant Prop Soc. 1966:16:287-90.

21. Scagel C. Cultivar specific effects of mycorrhizal fungi on the rooting of miniature rose cuttings. J Environ Hortic. 2001;19(1):15-20.

22. da Silva JAT. The cut flower: postharvest considerations. J Biol Sci. 2003:3:406-42.

23. Day DA, Hanson JB. Pyruvate and malate transport and oxidation in corn mitochondria. Plant Physiol. 1977;59(4):630-5.

24. Osmond C, Laties GG. Compartmentation of malate in relation to ion absorption in beet. Plant Physiol. 1969;44(1):7.

25. Ting I. Towards a model for malate accumulation in plant tissues. Plant Sci Lett. 1981;21(3):215-21

26. Lopez-Bucio J, Nieto-Jacobo Ml. Organic acid metabolism in plants: from adaptive physiology to transgenic varieties for cultivation in extreme soils. Plant Sci. 2000;160(1):1-13.

27. Tagliavini $M$, et al. Agronomic means for the control of iron deficiency chlorosis in deciduous fruit trees. J Plant Nutr. 2000:23(11-12):2007-22.

28. Abadía J, et al. Organic acids and Fe deficiency: a review. Plant Soil. 2002:241(1):75-86

29. Álvarez-Fernández A, et al. Foliar fertilization to control iron chlorosis in pear (Pyrus communis L.) trees. Plant Soil. 2004;263(1):5-15.

30. Eidyan B, Hadavi E, Moalemi N. Pre-harvest foliar application of iron sulfate and citric acid combined with urea fertigation affects growth and vase life of tuberose (Polianthes tuberosa L.)'Por-Par'. Hortic Environ Biotechnol. 2014;55(1):9-13.

31. Jafari N, Hadavi E. Growth and essential oil yield of dill (Anethum graveolens) as affected by foliar sprays of citric acid and malic acid. Acta Hortic 2012:955:287-90

32. Jaafari N, Hadavi E. Growth and essential oil yield of basil (Ocimum basilicum L.) as affected by foliar spray of citric acid and salicylic acid. Z Arznei Gewurzpfl. 2012;17(2):80-3. 
33. Darandeh $\mathrm{N}$, Hadavi E, Shoor M. Effect of $\mathrm{FeSO}_{4}$, methanol and $\mathrm{H}_{2} \mathrm{SO}_{4}$ sprays on chlorophyll content of lilium'Brunello'. Acta Hortic. 2010;900:217-21.

34. El-Tohamy W, et al. Drought tolerance and water status of bean plants (Phaseolus vulgaris L.) as affected by citric acid application. J Appl Bot Food Qual. 2013;86(1):212-6.

35. Mirzajani Z, Hadavi E, Kashi A. Changes in the essential oil content and selected traits of sweet basil (Ocimum basilicum L.) as induced by foliar sprays of citric acid and salicylic acid. Ind Crops Prod. 2015;76:269-74.

36. $\mathrm{Hu} L$, et al. Exogenous application of citric acid ameliorates the adverse effect of heat stress in tall fescue (Lolium arundinaceum). Front Plant Sci. 2016;7:179.

37. Cheniany M, et al. Effect of endogenous phenols and some antioxidant enzyme activities on rooting of Persian walnut (Juglans regia L.). Afr J Plant Sci. 2010:4(12):479-87.
38. Li S-W, et al. IBA-induced changes in antioxidant enzymes during adventitious rooting in mung bean seedlings: the role of $\mathrm{H}_{2} \mathrm{O}_{2}$. Environ Exp Bot. 2009;66(3):442-50.

39. Pivetta K, et al. Effect of type of cuttings and indolbutyric acid on the rooting of rose (Rosa sp'. Red success') leafy cuttings during two seasons. Acta Hortic. 1997;482:333-8.

40. Hwang $\mathrm{CH}$, et al. Rooting and growth affected by physiological condition of the stock plant for cutting propagation of roses. Propag Ornam Plants. 2015;15(3):95-100.

41. Talebi M, Hadavi E, Jaafari N. Foliar sprays of citric acid and malic acid modify growth, flowering, and root to shoot ratio of gazania (Gazania rigens L): a comparative analysis by ANOVA and structural equations modeling. Adv Agricul. 2014;2014:147278. https://doi. org/10.1155/2014/147278.

\section{Submit your manuscript to a SpringerOpen ${ }^{\circ}$ journal and benefit from:}

- Convenient online submission

- Rigorous peer review

- Open access: articles freely available online

- High visibility within the field

- Retaining the copyright to your article

Submit your next manuscript at springeropen.com 